\title{
The Perception of Petra Christian University Students Towards the Connection Between "Converse" Brand and Its "Proud to Be" Statement on Its T-Shirt Line
}

\author{
Samuelita Dayu Maharani \\ English Department, Faculty of Letters, Petra Christian University Surabaya, East Java, Indonesia \\ e-mail: samuelitadayu@gmail.com
}

\begin{abstract}
This thesis mainly deals with the theory of perception and decoding process to observe how Petra Christian University students perceive the connection between Converse brand and the use of language in one of its T-shirt products, "Proud to be". From the analysis, the researcher found out that the students could draw a line between the brand and its statement on its T-shirt design. This means that "Proud to be" statement is considered a success as a code to express the company's message to its consumers and suits the brand personality of Converse. In conclusion, the language used in product design is able to communicate the brand personality.
\end{abstract}

Key Words: perception, decoding, language use, product design, brand personality.

\section{INTRODUCTION}

A well-known brand for its "Chuck Taylor" sneaker has been presented for more than a hundred years. Now, considering its age, Converse still exists with its famous name. The shoe was made for soccer and netball at first, then as basketball popularity was rising, in 1917, Converse released its first basketball shoe, the Converse All Star. It was a big cultural shift in the 70s that Converse was no longer seen as basketball shoe but a part of lifestyle option and started to avail in various new colors versions in 1971.

Recently, Converse released a new collection called Pride in America, 2017. They offer colorful designs on sneakers and T-shirts as complimentary product that the profit from this collection will go to the It Gets Better Project and The Happy Hippie Foundation. These two organizations committed to support LGBTQ (Lesbian, Gay, Bisexual, Transgender, and Queer) youth around the world. As being supportive as it is, the company uses language to communicate the message to their customers. They use positive writings on the website and statements in the product design, such as "Proud to be" writing on its T0shirt design.

The researcher of this thesis see that this phenomenon is a language function in marketing and product designing. Both activities, marketing and product designing, should be harmonious in communicating the message the company wants to communicate to its customers. In product design like T-shirt and any other apparel commodity, it does not only include art and graphic. It can be language added to emphasize the message as Bruner and Emery said that, "..., well defined vocabulary to make things fit together. You construct your design statement using this vocabulary" (Bruner, R. \& Emery, S., 2009, p. 177). This means that language, and any other feature, used in the product design should build the message completely, so the consumer could understand the message wholly. For this reason, a brand like Converse must make everything in its product design clear enough for the customer to understand the real message regarding its campaign. This is not a mere reason whether to understand what the message of the product is. Instead, it is important to make the customers understand the personality of a brand that they could differentiate one brand from another. Their understanding about the brand influences their behavior (will they trust the brand, will they buy its product, and so on).

In this study, the researcher aims to analyze the connection between "Proud to be" statement on T-shirt as a part of Pride campaign and Converse's brand personality, since there must be an alignment between the brand and any statement it releases, such as tagline, slogan, and part of product design that people could perceive. The analysis is based on the twelve participants' 
perception that are the representatives of Petra Christian University students. Therefore, the researcher uses the theory of perception by Schiffman and Kanuk to examine how the participants perceive the connection. Along with it, the researcher uses semiotics as supporting theory to deal with language used in T-shirt design as well as the theory of perception. Here, the theory of decoding by Chandler is used to analyze the participants' perception.

\section{METHOD}

The researcher used qualitative research approach because it aims at observing how the participants perceive the connection between Converse brand and "Proud to be" statement. The researcher used words rather than numbers in analyzing the data which were taken from semistructured interviews with twelve participants. For this study was about perception, the result might differed from one participant to the others. It was because qualitative research like this study was "focusing on the unique meaning carried by individual organism" (Dörnyei, 2007, p. 29). Therefore, using matrix in data analyzing was the most effective way for this study, instead of using charts, numbers and percentages.

The data used in this research were collected from semi-structured interview as instrument to get participants' opinion. The researcher picked twelve students from Petra Christian University, whereby two were taken to represent each faculty, one male and one female student. Also, the researcher also took Converse's new statement on T-shirts from Nike's official store website at store.nike.com for Converse was under the leadership of Nike's company. The semi-structured interview contained seven guiding questions in Bahasa Indonesia that needed to be answered by the participant also in Bahasa Indonesia.-The researcher made the interview sheet into table functioned as a note sheet that was written down by the researcher during the interview. The researcher ran a pre-test of the interview's questions to test out the questions' reliability in digging the participants' answer then, after revising, the researcher runs the real interviews with the participants. Knowing that writing down the participants' response in detail on the spot was hard while listening to them, the researcher initiatively recorded the participants' response using mobile phone's voice recorder then transcribed it.

In the interview, the researcher asked the participants how they perceived Converse's brand personality. The researcher asked each of them to give three brand images that they recognized in Converse and allowed them to elaborate their opinion. Then, the researcher asked them how they decoded the meaning of "Proud to be" and its rainbow color as its context was. Last, the participants were asked how they perceived the connection between the statement, along with the color, and the brand image according to them.

\section{ANALYSIS AND FINDINGS}

In order to answer the research questions, the researcher analyzes three things:

- The decoded meaning of "Proud to be" statement and its rainbow color

- The perception of Converse brand

- The connection between "Proud to be" statement, rainbow color, and Converse brand

\section{The decoded meaning of "Proud to be" statement and its rainbow color}

In this part, the researcher discovered how the participants take meaning on "Proud to be" and rainbow color. The researcher's analysis is taken from the general and majority participants' responses. The researcher divided the analysis into two parts: first, the decoded meaning of "Proud to be" statement, and second, the decoded meaning of rainbow color.

\section{The decoded meaning of "Proud to be" statement}

In response of question "menurutmu, apa arti dari "Proud to be" (in your opinion, what does "Proud to be" mean)?", half of the participants have similar answers that are included in the same cluster, which is "proud to be myself". The other half of them have different answers, such as "proud to wear Converse", "proud to be different from other brands", "proud to be anything", and "proud to be something". From the number of participants, the researcher considers "proud to be myself" response as majority answer to represent the decoded meaning of "Proud to be" statement in general. 
Table 2 the decoded meaning of "Proud to be" statement

\begin{tabular}{|c|c|}
\hline Decoded meaning & Reason \\
\hline Proud to be myself & 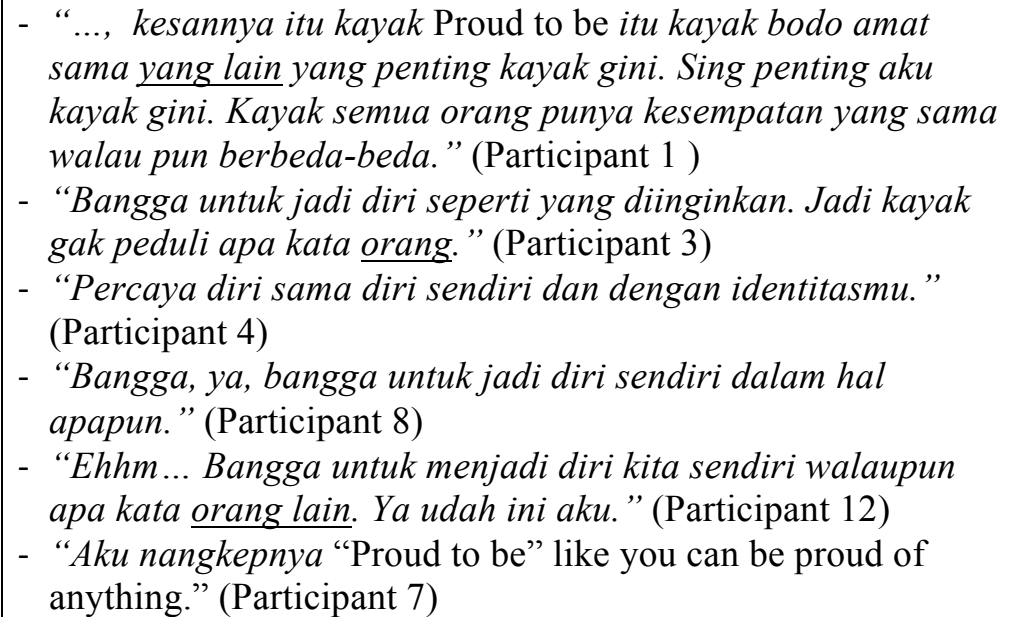 \\
\hline
\end{tabular}

From the table above, the researcher discovered that there is an ignorance in their response. Three of these six participants mentioned words "yang lain", "orang", and "orang lain" refering to other people. By saying that, they meant that being proud of themselves was to be ignorant to what other people say about them, and that was okay to be their own selves. These words also shows that to be proud of themselves is not to follow the trend or the majority. Instead, we need to follow what we think is good and be "masa bodo (indifferent)" to what people say. The action of being proud of ourselves is not only by showing it through the clothes we wear but also by showing our pride in other things. This is like what one of the participants says that, "bangga untukjadi diri sendiri dalam hal apapun (being proud to be ourselves in anything)." We can be proud of our hobies and talents, for example. We can also be proud of our personality, like being friendly and witty to anyone since not everyone could be like this to everyone they meet, or other things as another participants says that we "can be proud of anything."

The researcher also found out a relative connection between being proud and selfconfidence in one of the participants's responses. She said that being proud of ourselves meant being confident with ourselves and with our identity ("percaya diri sama diri sendiri dan dengan identitasmu"). There are two things in her saying that are important. First, being proud of ourselves means being confident with ourselves for elf-confidence is essential in order to be proud of ourselves. There are many people doubt themselves and and being timid of who they really are. Second, being confident is not only about physical things: being physically strong or weak, complete or incomplete, but it is also about identity, such as gender, nationality, age, race, ethnicity, occupation, religion, economic status, education, sexual orientation, and many more things.

By giving those examples of action of being proud, the researcher does not imply that we have to always oppose our society, become a rebel, and do harmful things. To be proud of ourselves is to be our own selves without any force form other people. The society can shape us, but it does not mean that we do not have any opportunity to transform ourselves. "..., semua orang punya kesempatan yang sama walau pun berbeda-beda (everyone has the same opportunity eventhough they are different)", says one of the participants. One person is different from other person in terms of personality, way of learning, way of thinking, likes, dislikes, any many other things. That means each person has different way to do something from others and they have the same change to be themselves and to be whatever they want.

\section{The decoded meaning of the rainbow color}

Having asked the participant question "menurutmu, arti warna pelanginya apa? (in your opinion, what does the rainbow color mean?), the researcher found out that more than half of the 
participants, or seven of twelve participants, see that the multi-colored font in the T-shirt's design represents LGBT issue. It leads the researcher to take it as the general responses given by the participant towards the rainbow color.

Table 3 the decoded meaning of rainbow color

\begin{tabular}{|c|c|}
\hline Decoded meaning & Reason \\
\hline LGBT's color & $\begin{array}{l}\text { - “.., mungkin karna LGBT selalu di sandingkan dengan pelangi. } \\
\text { Pelangi itu LGBT, kayak terpatri.” (Participant 1) } \\
\text { - “Soal'e nek diliat-liat gini, ini mek satu aja yang menonjol, } \\
\text { warna putih'e, dan yang lainnya sama warna-warni. Karena } \\
\text { menurutku LGBT itu bisa di bilang hubungan sosial yang paling } \\
\text { beda, yang lain cewe-cowo, LGBT beda sendiri. Gitu.” } \\
\text { (Participant 3) } \\
\text { - “..., rainbow itu selalu dikaitkan dengan LGBT.” (Participant 4) } \\
\text { - “Biasa'e sih, rainbow gitu itu hubungan'e mbe LGBT. Warna- } \\
\text { warni'e kek rainbow itu lak kayak bendera'e LGBT.” (Participant } \\
\text { 6) } \\
\text { - "Like rainbow color is for LGBT, right?” (Participant 7) } \\
\text { - “Well, karena ini lak kayak multicolor, kan kayak mungkin the } \\
\text { issue recently adalah LGBT. Dan dari beberapa taun-taun lalu } \\
\text { jarang ada tema rainbow untuk fashion, tapi semenjak LGBT } \\
\text { dilegalkan, tema rainbow sering muncul dalam fashion.” } \\
\text { (Participant 8) } \\
\text { - “Hmm, tapi kok ini agak mirip sama sesuatu ya, warna'e. Warna- } \\
\text { warni. Pelangi. Jangan-jangan ini tentang LGBT, ya?" } \\
\text { (Participant 10) }\end{array}$ \\
\hline Cultural diversity & $\begin{array}{l}\text { - "Soalnya kalo aku melihat di Amerika itu lebih banyak } \\
\text { bermasalah culture daripada LGBT. Soalnya kan kayak di sana } \\
\text { itu kayak gay, lesbian itu udah merit, dan udah legal kalo disana. } \\
\text { Lain ceritanya kalo misalnya kita di neggara Asia. ..., disana kan } \\
\text { cultural-nya, misalnya kayak rasis itu menurut aku masih parah } \\
\text { gitu, lho" (Participant 5) }\end{array}$ \\
\hline
\end{tabular}

More than half of the participants believe that rainbow color surely means LGBT. It is apparently because that rainbow color is for LGBT is embeded on their mind that everytime they see rainbow color, they will unconsciouly refer to LGBT. Other participants are aware that rainbow color is LGBT's flag. That is how they relate rainbow color and LGBT. Their experience and knowledge about LGBT's flag leads them to their opinion about rainbow color.

Besides it is about LGBT, there is another possibility of what the meaning of its rainbow color is. This multi color can be seen as representing cultural diversity. The supporting evidence of this argument is that this collection is released in United State of Amerika in which LGBT issues is not the major problem. One of the participants said that, "..., America has more problems with culture than LGBT (Amerika itu lebih banyak bermasalah culture daripada LGBT)." The underlining reason of this is because gay couples' marriage in America has already been legalized. There are more cultural problems such as bullying over black people, Hispanic or Asians in America.

\section{The perception of Converse brand}

The researcher discovers several perceptions toward Converse brands taken from their answer for question "3 kata apa yang menurutmu menggambarkan Converse? (What are 3 words best describe Converse in your opinion?)". From their responses, there are thee perceptions representing what kind of brand Converse is. First, Converse is seen as casual which will be discussed in the first section. Second, Converse is seen as classic which will be discussed in the 
second section. Last, Converse is seen related to freedom which will be discussed in the third section.

\section{The perception of "Converse" brand as "Casual"}

More than half of the participants, or seven of them, gave responses implying that Converse was casual. When the researcher asked them why in the interviews, they had similar responses.

Table 4 the perception of Converse brand as "casual"

\begin{tabular}{|c|c|c|c|c|c|c|c|}
\hline Participant & 10 & 2 & 11 & 1 & 12 & 4 & 6 \\
\hline Reason & $\begin{array}{l}\text { “..., } \\
\text { bisa } \\
\text { dipake } \\
\text { kapan } \\
\text { aja } \\
\text { waktu } \\
\text { santai. } \\
\text { " }\end{array}$ & $\begin{array}{l}\text { "Ya, } \\
\text { emang } \\
\text { pas } \\
\text { dibuat } \\
\text { casual, } \\
\text { gak } \\
\text { cocok } \\
\text { kan nek } \\
\text { dipake } \\
\text { sama jas } \\
\text { or } \\
\text { tuxedo." }\end{array}$ & $\begin{array}{l}\text { "..., } \\
\text { model' } \\
\text { e cocok } \\
\text { buat } \\
\text { kaos, } \\
\text { celana } \\
\text { pendek } \\
\text { juga } \\
\text { oke. } \\
\text { Pas } \\
\text { gitu." }\end{array}$ & $\begin{array}{l}\text { "Nggak } \\
\text { pake } \\
\text { corak- } \\
\text { corak } \\
\text { ato } \\
\text { model } \\
\text { sing } \\
\text { aneh- } \\
\text { aneh, } \\
\text {...” }\end{array}$ & $\begin{array}{l}\text { "..., } \\
\text { nggak } \\
\text { norak, } \\
\text { nggak, } \\
\ldots, \\
\text { nggak } \\
\text { menco- } \\
\text { lok } \\
\text { banget } \\
\text { gitu." }\end{array}$ & $\begin{array}{l}\text { ".., } \\
\text { bisa } \\
\text { dipake } \\
\text { keman } \\
\text { a- } \\
\text { mana." }\end{array}$ & $\begin{array}{l}\text {..., } \\
\text { mau } \\
\text { ngapa- } \\
\text { ngapai } \\
\text { nitu } \\
\text { enak di } \\
\text { pake. }\end{array}$ \\
\hline
\end{tabular}

From the table above, the researcher found out why these participants said that Converse was casual. It is because Converse is for casual or informal occasion, has simple design and is comfortable. Basically, Converse's shoe was made for basketball players and later its function becomes less sporty. Now it is mainly worn by young people when they go to school or go skateboarding or any less formal occasion. In any "leisure time (waktu santai)", like what participant 10 said, Converse is a good option also, mixed-and-matched with T-shirts and shorts. That is why Converse is not recommended for formal occasions when "suits or tuxedo" needed, like participant 2 said. Next, Converse is casual because, compared to other shoe brand, Converse has simplest design. Almost all of its design "has no pattern or intricate model (nggak pake corakcorak atau model sing aneh-aneh)". Other brands nowadays compete with bright color and some patterns added, but Converse competes with their simple design. Even though it is simple, Converse is still choosen for, according to participant 12, "it is not tacky (gak norak)". People willingly wear Converse because they will feel they have good taste in fashion. Converse is not "mencolok" or conspicuous to wear, so people can wear it to anywhere and to do anything, especially in any informal time, for it is comfortable.

\section{The perception of "Converse" brand as "Classic"}

The second perception about Converse is that it is classic. Seven participants have given responses that support this perception. Here is the table containing their opinion.

Table 5 the perception of Converse brand as "classic"

\begin{tabular}{|l|l|l|l|l|l|l|l|}
\hline Participant & \multicolumn{1}{c|}{3} & \multicolumn{1}{c|}{5} & \multicolumn{1}{c|}{6} & \multicolumn{1}{c|}{7} & \multicolumn{1}{c|}{8} & \multicolumn{1}{c|}{11} & \multicolumn{1}{c|}{12} \\
\hline Reason & "Dari & “.., & “.., & "Sejauh & "Style- & “.., & "Fashi \\
& dulu & dari & bentuk'e & ini ya & nya & dia & on-able \\
& sampe & dulu & kan & gitu-gitu & terkesa & jaman & karena \\
& sekaran & sampe & kebanya & aja. & nlama, & New & bisa di \\
& g gak & sekaran & k-an & Design'e & colorin & Balanc & pake \\
& ada & g & classic- & gak & g-nya & e & mau \\
\hline
\end{tabular}




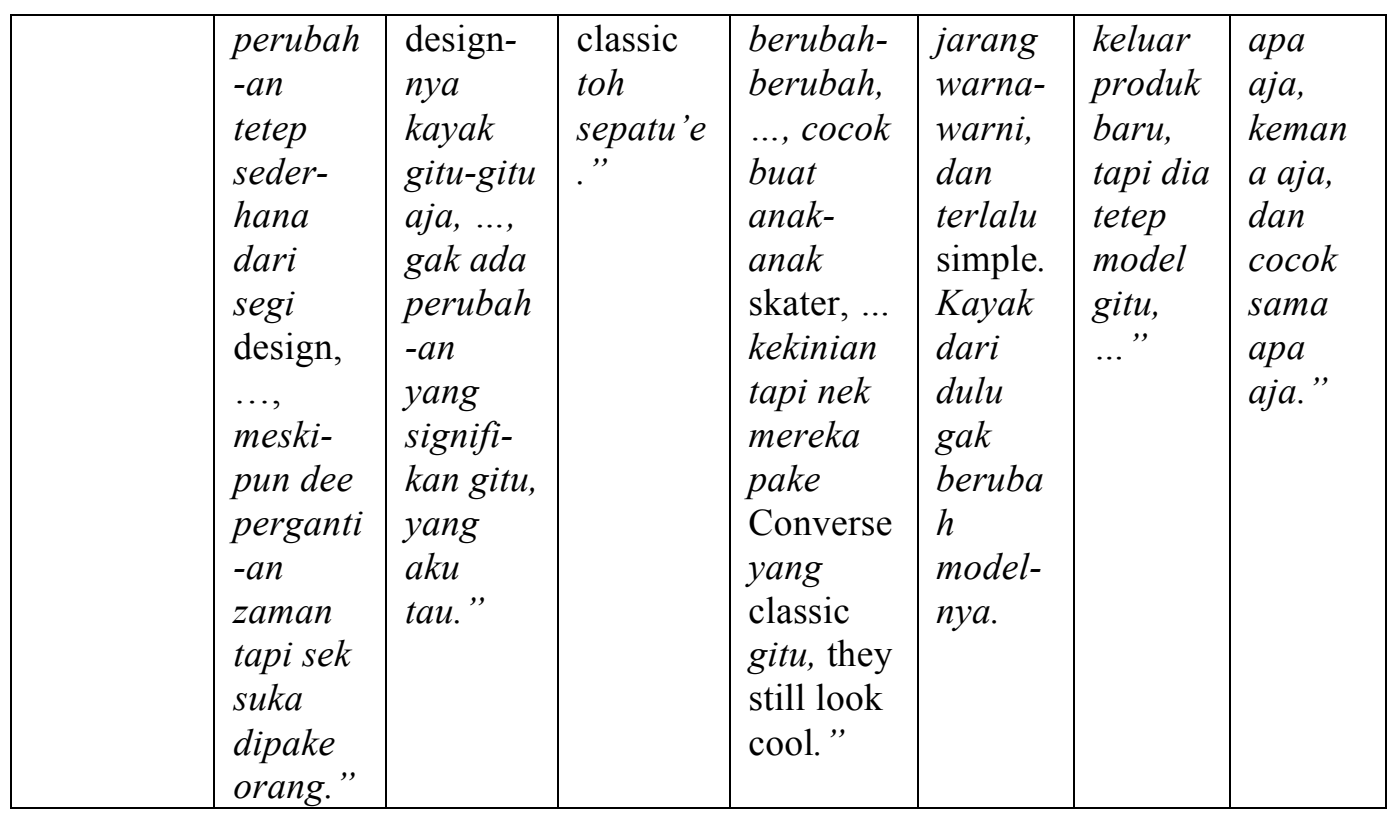

The first thing about Converse being classic is that its consistency in design. When we compare the shoe design of Converse and other well-known shoe brand, we can name the difference very well. If other brands use modern design and pattern and sometimes use eyecathcing colors in one shoes, Converse remains using solid color and white sole in its simple design. This characteristic of Converse's design is taken from the old Converse All-Star with its white, thick, rubber sole, white rubber cap, and canvas material. The participants recognize this unchanged design when they say things like "gak ada perubahan, tetep sederhana (no changes, still simple)", "kayak gitu-gitu aja, ..., gak ada perubah-an yang signifi-kan (like it is, ..., no significant changes)", and "Style-nya terkesan lama, coloring-nya jarang warna-warni (its style looks old, and its coloring is rarely colorful)". Nevertheless, Converse is still considered suitable for the style of young people. Because there are many skateboarder wear Converse, this shoe is famous as skater's shoes, and skateboearders are seen cool by some young people. It is classic yet not old-fashioned. One of the participant said that Converse was in, trendy, so "now", or "kekinian", and it was cool. Another perticipant's reponse also gives the same view about Converse. She said Converse was fashionable that wearing it is easy to mix and match. That is how the participant see the classic-yet-still-fashionable Converse.

\section{The perception of "Converse" brand as "Freedom"}

The last perception about Converse is freedom. Below is the table of their opinion.

Table 6 the perception of Converse brand as "freedom"

\begin{tabular}{|l|l|l|l|}
\hline Participant & 1 & 10 & 2 \\
\hline Reason & "Menurutku secara & "Karena bisa di & "Soale'e orang- \\
& bersamaan kalo pake & mix and match & orang sing pake itu \\
& Converse itu jadi punya & dengan pakaian & kebanyakan orang \\
& "kebebasan" tersendiri buat & apa aja. Kayaknya & sing gak bisa \\
& bergaya atau memadu- & pake Converse & dikekang or gak \\
& padankan apa yang bakal & dengan dress still & nyaman sama \\
& kamu pake atau apa yang & okay gak, sih?" & rutinitas sing sama \\
& akan kamu tampilkan ke & & buat jangka waktu \\
& orang-orang." & & lama." \\
\hline
\end{tabular}

Like the previous perceptions, the participants perceive that Converse is about freedom from its design. There are two reasons why Converse is seen "free": 1.) it is free to mix and match, and 2.) it is convenience to wear when in high activities. The first reason is based on the perception 
that Converse is casual. For its simple design and easy to mix-and-match with other casual outfit, the wearer of Converse has freedom to choose what he/she wants to wear. It is like what participant 1 said that,

"..., wearing Converse is like having "freedom" to make style or mix-and-match what you want to wear or what you want to show to the people (..., pake Converse itu jadi punya "kebebasan" tersendiri buat bergaya atau memadu-padankan apa yang bakal kamu pake atau apa yang akan kamu tampilkan ke orang-orang)."

For this participant, to wear Converse is not only free to mix-and-match it with other fashion items, but it is also free to make your own style. When you want to look more classic, you can wear it with something vintage, such as polkadot, vintage dress with sunglasses. When you want to look more edgy, you can wear it with ripped jeans, T-shirt, and leather jacket. It is up to you to choose what kind of style you want to wear for a day with Converse, as long as it is in casual occasion.

The second reason that Converse is convenient to wear in high activities is also based on the peception that Converse has simple design. Its simple design is not only easy to wear but also comfortable to wear. Participant 2 argued that those who wore Converse usually were people that could not be chainned or not comfortable with the same routine in a long period ( "...., orang-orang sing pake itu kebanyakan orang sing gak bisa dikekang or gak nyaman sama rutinitas sing sama buat jangka waktu lama"). This means that the wearer of Converse is usually people with high activity who, in a longer period, has several activities to do. They usually tend to jump from one activity to another activity. Because of this active condition, they need something comfortable on their feet that makes it free to do their things, and Converse is seen perfect for this kind of wearer because its simple and comfortable shape.

\section{The connection between "Proud to be" statement, rainbow color, and "Converse" brand}

In this part, the researcher explains the findings on whether the participant get the connection between the "Proud to be statement, rainbow color, and "Converse brand. There are two distinct responses the researcher got from the interview that most of the participants got the connection that "Proud to be" statement and rainbow color represent the personality of the brand, "Converse" and that the rest of the participants hardly understood the connection between the three of them.

\section{There is connection between "Proud to be" statement, rainbow color, and "Converse" brand}

According to the table below, we can see several participants's opinion about the connection between "Proud to be" statement, the rainbow color, and "Converse" brand. Their responses were related to their own perception about "Converse". It is no surprise that they had different reason of saying that "Proud to be" satement, and even the rainbow color", are connected to their perception about "Converse". This means that the participants could see that the messages coded in "Proud to be" statement and the rainbow color match the perconality of "Converse" perceived by them.

Table 7 there is connection between "Proud to be" statement, rainbow color, and Converse brand

\begin{tabular}{|c|c|c|l|}
\hline Participant & Yes & No & \multicolumn{1}{c|}{ Reason } \\
\hline 1. & $\mathrm{~V}$ & & $\begin{array}{l}\text { Aku liat'e kan nyambung sama freedom dan authentic. } \\
\text { Karena authentic kan artinya mirip original. Jadi sama kayak } \\
\text { "proud to be the original me" gitu. Nyambung juga sama } \\
\text { freedom karena kan kamu free mau kayak gimana, mau } \\
\text { proud tentang apa, mau ngomong apa. Terserah gitu, lho. }\end{array}$ \\
\hline 3. & $\mathrm{~V}$ & & $\begin{array}{l}\text { Nyambung ae, karena setiap pengguna'e jika pake produk } \\
\text { Converse merasa lebih percaya diri ato bangga atas dirinya. } \\
\text { Jadi kayak tulisan itu merepresentasikan kalo dia percaya } \\
\text { diri. Ini agak nyambung mbe image simple-nya. Soal'e kan, } \\
\text { misal, orang yang gak percaya diri itu gak bakal pake baju } \\
\text { yang ribet-ribet atu aneh-aneh. Nah Converse punya design }\end{array}$ \\
\hline
\end{tabular}




\begin{tabular}{|c|c|c|l|}
\hline & & & $\begin{array}{l}\text { yang simple yang bisa bikin orang percaya diri. Dan design } \\
\text { T-shirt ini juga simple. Walaupun warna-warni design'e ini } \\
\text { tetep keliatan simple menurutku. }\end{array}$ \\
\hline 5. & $\mathrm{~V}$ & $\begin{array}{l}\text { Ya kan, kayak yang aku bilang tadi, Converse itu image-nya } \\
\text { vintage. Dan sedangkan brand-brand lain itu modern. Dia } \\
\text { pede aja gitu, lho menyuguhkan produknya yang vintage di } \\
\text { era modern ini. Jadi, kesannya kayak dia proud to be itself, } \\
\text { entah brand lain mau kayak apa, ya dia tetep vintage gitu. }\end{array}$ \\
\hline 6. & $\mathrm{~V}$ & $\begin{array}{l}\text { Soal'e bentuk sepatu'e lak kebanyakan kayak casual-casual } \\
\text { gitu toh. Berarti kayak orang sing make kayak mempunyai } \\
\text { kebebasan dengan apa yang dia mau buat penampilan. Nah, } \\
\text { karena bebas itu kan jadi'e keluar pride'e orang itu, terus ya } \\
\text { bangga otomatis dengan apa sing dee pake. }\end{array}$ \\
\hline 7. & $\mathrm{~V}$ & $\begin{array}{l}\text { Dia satu-satunya gitu, lho. Mereka itu isa bangga with being } \\
\text { classic di tengah-tengah persaingan sama Nike, Puma, and } \\
\text { friends. }\end{array}$ \\
\hline 10. & $\mathrm{~V}$ & $\begin{array}{l}\text { Kalo di pikir-pikir, mestinya nyambung-nyambung aja. } \\
\text { Soalnya Converse kan freedom gitu, jadi mendukung } \\
\text { "kebebasan" apapun, termasuk kebebasan untuk jadi LGBT. }\end{array}$ \\
\hline 11. & $\mathrm{~V}$ & $\begin{array}{l}\text { Soalnya model'e simple. Ehm, dibuat kemana-mana itu oke } \\
\text { gitu. Jadi orang sing sering pake Converse karena bisa } \\
\text { dipake sama apa aja kemana aja itu arti'e bangga pake } \\
\text { Converse }\end{array}$ \\
\hline
\end{tabular}

There are several connections between the perception about Converse brand, the "Proud to be" statement, and the rainbow color. First, the "proud to be my self" from the statement and "LGBT" issue from the rainbow color is related to the "freedom" perception of Converse. It is somewhat like perticipant 1 said that we got the in anything we want. She said, “..., you can be free anyhow, what you want to be proud of, what you want to say. It's up to you ( $k a m u$ free mau kayak gimana, mau proud tentang apa, mau ngomong apa. Terserah gitu, lho)." This "freedom" also goes to the more specific thing, like sexual orientation. Participant 10 mentioned in the interview that it was about things like being LGBT. This means that Converse is being supportive with freedom, in this case, being LGBT.

Second, the "proud to be myself" from the statement and the "cultural diversity" from the rainbow color are related to the classic perception about Converse. From the interview with the participants, the researcher found out that the participants really thought Converse was still being classic with its unchanged design. Even though many brands have developed and improved the design of their products, Converse remains the same. This looks like Converse is being proud with their classic-ness. No matter how the universal shoes business goes, they will keep their character that way. One of the participants said that, “..., it (Converse) is proud to be itself. No matter how the other brands are, it remains vintage (..., dia proud to be itself, entah brand lain mau kayak apa, ya dia tetep vintage gitu)". This is actually an example for the people to keep being themselves. Converse wants to give an example to not be ashamed with the original version of ourselves. We can still exist with being authentic that makes us different from other people. Our background, such as ethnicity, race, religion, gender, and many more, makes us a unique individual, and that is a good thing to be proud of. Even another participant related this "being proud" and "being classic/authentical" with the reality we have now among the young people. She saw that nowadays young people tend to follow the trend that they did not recognize whether the trend was good or not, useful or not. They can not stand on their own feet, always try to follow what is in instead of doing something on their own ways or style. "..., nowadays kids (young people) just follow the trend and maybe from now on, we, young people, do not be like that (..., anak sekarang itu mek ikut-ikutan dan mungkin mulai dari kita anak-anak muda ini isa sing jangan kayak gitu)," she said. This is supposedly not to happen, and Coverse is being a good example of being proud.

The next thing is that there is connection between the "being proud" statement and "casual" perception about "Converse". Because of its simple design, people can wear Converse in 
any casual occasions. It is what makes many people wear Converse. For this reason, the second participant thinks that Converse is such a "must-have" fashion item, as he said, "such a must-have item (koyok barang wajib punya ngono lho)", and that the wearers should be proud of it that they could wear such thing. So, there is proudness in wearing Converse that is relatable with "Proud to be" statement. Also, the Converse is seen able to raise the self-confidence of the wearer, especially those who are not comfortable with eye-castching stuffs, because of its simple design. One of the participants gave an example of a person who was not confident wearing unordinary outfit or which she called "aneh-aneh". By wearing simple outfit such as Converse, this person could raise his/her confidence that was represented by "Proud to be" statement on the T-shirt.

\section{There is no connection between "Proud to be" statement, rainbow color, and "Converse" brand}

Only two of the twelve participants could not see the connection between "Proud to be" statement, the rainbow color, and "Converse" brand.

Table 8 there is no connection between "Proud to be" statement, rainbow color, and Converse brand

\begin{tabular}{|c|c|c|l|}
\hline Participant & Yes & No & \multicolumn{1}{|c|}{ Reason } \\
\hline 4. & & V & $\begin{array}{l}\text { Lagian kata "Proud to be"-nya lebih mengarah ke public } \\
\text { yang luas, muda tua, sedangkan biasanya ke public yang } \\
\text { lebih muda. }\end{array}$ \\
\hline 8. & & V & $\begin{array}{l}\text { Kalo aku liat, seh, kayak nggak ada hubunganya. Aku gak } \\
\text { paham sih apa hubungannya Converse sama "Proud to be" }\end{array}$ \\
\hline
\end{tabular}

The fourth participant thinks that the statement is directed to a wider range of age of the target market. It seems there is no relevant connection between the "Proud to be" statement and Converse. She probably thinks that "Proud to be" means to proud to be ourselves and to proud with our identity. It means we should be proud of anywho we are, including no matter how old we are. This meaning is not relevant with her perception about "Converse" as a "youth" brand.

The most interesting finding in this research is what the researcher got from participant 8. All of the other participant could give explanation about if they see the connection between "produ to be" statement, the rainbow color, and "Converse" brand. However, this one participant could give any explanation on why he said that there were not any relevant connection between the three of them (the statement, the color, and the brand). Even though the resercher had explained further about what kind of thing she meant by "connection" between the three of them, this participant still gave the same answer to the researcher. He said in the interview, "I still don't understand. I mean the connection between "Proud to be" and the image (Aku masih, gak paham sih. Maksudku kaitannya apa "Proud to be" sama image-nya). "Probably it is because the connection between the statement, the color, and the brand is too far for him to understand even after the long explanation from the researcher.

\section{CONCLUSION}

From the analysis and findings, the researcher found out that the participants decoded "Proud to be" as a message for us to be "proud of ourselves". It is something like being proud of the original version of ourselves who are not following the mainstream. Then, the participants decoded the rainbow color as the context of the statement as a symbol of LGBT as they recognized that LGBT flag was rainbow colored. Also, the researcher found out several things about Converse as a brand perceived by the participants. Converse is seen as casual, classic, and freedom-related brand. Its simple design makes Converse comfortable and is good for informal moments. This simple design also remains the same like the classic version of Converse All Star that makes Converse unique from other shoe brands. For these two perceptions, Converse is seen being supportive to any kind of freedom. Then, the researcher found out that most of the participant could recognize the 
relative connection between "Proud to be" statement, the rainbow color, and Converse brand. The meaning of "Proud to be" and rainbow color perceived by the participant is seen related to the perception about Converse that it is casual, classic, and freedom-related. Generally, "Proud to be" and rainbow color is seen representing Converse being proud of its "classic" personality in this modern era and being supportive to any kind of liberty, especially the liberty of the LGBTs.

In conclusion, from this study, the researcher knows that these three things are related to each other. The statement and the color are related to the personality of the brand which is seen as successful codes to express the message from the brand to the society. The meaning of "Proud to be" and rainbow color are still related to the personality of Converse that the participant can generally perceive the message correctly. If Converse were not using statements like this one and this rainbow color, people would not get the message correctly, and the decoding and perceiving process would be failed. Here, the appropriate use of language, or any other codes, in product design such as T-shirt is needed.

\section{REFERENCES}

Abigail, S. M. 2014. The Perception of Petra Christian University male and female students toward the language used in a hotel website and the hotel itself. Unpublished thesis: Petra Christian University.

Bengtson, R. 2013, May 29. 50 Things You Didn't Know About Converse Chuck Taylor All Stars. Retrieved from: http://www.complex.com/sneakers/2013/05/50-things-you-didnt-knowabout-converse-chuck-taylor-all-stars/

Brunner, R., Emery, S. 2009. Do you matter? : How great design will make people love your company. New Jersey: Pearson Education, Inc.

Chandler, D. 2007. Semiotics: the Basics $-2^{\text {nd }}$ edition. New York: Routledge.

Chandler, D. (n.d.). Semiotics for beginners: Encoding/decoding. Retrieved from: http://visualmemory.co.uk/daniel/Documents/S4B/sem08c.html

The history of the Converse All Star "Chuck Taylor" basketball shoe. (n.d.) Retrieved from: http://www.chucksconnection.com/history $1 . h t m l$

Converse ft lead support associate Somerville, Massachusetts. (2017, September 25). Retrieved from: https://jobs.converse.com/job/somerville/converse-ft-lead-supportassociate/7232/5808121

Dörnyei, Z. 2007. Research methods in applied linguistics: quantitative, qualitative, and mized methodologies. Oxford: Oxford University Press.

Foreman. 2014. Converse shoes: in the all star game. Retrieved from: http://www.bbc.com/culture/story/20140606

Kusuma, S. 2010. The perceived meaning of various fast foods slogans and the reasons based on the background knowledge among the fast foods customers in Surabaya. Unpublished thesis: Petra Christian University.

Newcomb. 2015. The Chuck Taylor All Star: a story of the first signature sneaker. Retrieved from: https://www.si.com/nba/2015/02/27/converse-chuck-taylor-all-star-the-first

Schiffman, L., Kanuk, L. 2007. Consumer Behavior $-9^{\text {th }}$ edition. New Jersey: Pearson Education. 
Schultz, D., Barnes, B. 1999. Strategic Brand Communication Campaigns $-5^{\text {th }}$ edition. Illinois: NTC Business Book.

Yes to All. (n.d) Retrieved from: https://www.converse.com/us/en_us/c/converse/pride 